\title{
A NEW METHOD FOR THE BIOLOGICAL ASSAY OF CARDIOTONIC STEROIDS BASED ON THE POTEN- TIATION OF POTASSIUM-CONTRACTURE OF THE FROG VENTRICULAR MUSCLE
}

\author{
Keisuke TAKEDA*, Akira SAKUMA and Tatsuro SHIGEI** \\ Department of Pharmacology, Institute for Cardiovascular Diseases, \\ Tokyo Medical and Dental University, Bunkyo-ku, Tokyo
}

Received for publication December 28, 1970

So far there seems to have been no practical method for the assay of cardiotonic steroids which measures their positive inotropic activity per se directly on the cardiac muscle preparation. A series of studies on the structure-activity relationship of cardenolides conducted in this laboralory have brought about much newer knowledge on this problem, including dispensability of $3 \beta$-hydroxy group or $14 \beta$-hydroxy group for cardiotonic action and inactiveness of $15 \alpha$-hydroxydigitoxigenin (1-4). In the course of the study, it was felt necessary to describe the potencies of important compounds in terms of numerical values. This led us to develop a new assay method which is based on the potentiation of $\mathrm{K}$-contracture of frog ventricular muscle by these compounds, and it has been applied successfully at least to the aglycones. The present paper will report on the new method and the results of the assay of seven aglycones. In addition, the relative potencies of the compounds were compared with those obtained by another method with Straub's isolated frog heart preparation.

\section{MATERIALS AND METHODS}

The isolated ventricular strip preparation and the isolated heart preparation (Straub's preparation) of the frog (Rana nigromaculata) were used. Experiments were performed from May through September.

1) Isolated ventricular strip preparation: A circular strip was dissected out from the middle protion of the ventricle, and cut open to give a muscle preparation about $1 \mathrm{~mm}$ thick and $5 \mathrm{~mm}$ long. It was suspended in a $3 \mathrm{ml}$ organ bath containing Ringer's solution aerated with oxygen and maintained at temperature of about $25^{\circ} \mathrm{C}$. The composition of the nornal Ringer solution was: $\mathrm{NaCl}, 111 \mathrm{mM} ; \mathrm{KCl}, 2.7 \mathrm{mM} ; \mathrm{CaCl}_{2}, 1.8 \mathrm{mM}$; $\mathrm{NaHCO}_{3}, 1.2 \mathrm{mM}$; d-glucose, $2.7 \mathrm{mM}$. In the following experiments, the concentrations of $\mathrm{KCl}$ and $\mathrm{CaCl}_{2}$ were modified according to the purposes. For induction of K-contracture, a solution containing $60 \mathrm{mM}$ of $\mathrm{KCl}$ and $0.9 \mathrm{mM}$ of $\mathrm{CaCl}_{2}(60 \mathrm{mM} \mathrm{K}, 0.9 \mathrm{mM} \mathrm{Ca}-$ Ringer) was used. For measurement of the maximal K-contracture tension, a solution *Present address: Medical Research Laboratory, Central Institute for Experimental Animals, Nogawa, Kawasaki. **:Present address : Department of Pharmacology, Nagoya University, School of Medicine, Showa-ku, Nagoya. 
containing $110 \mathrm{mM}$ of $\mathrm{KCl}$ and $5 \mathrm{mM}$ of $\mathrm{CaCl}_{2}$ (110 mM K, $5 \mathrm{mM} \mathrm{Ca-Ringer)} \mathrm{was} \mathrm{used.}$ In these two cases, equivalent amount of $\mathrm{NaCl}$ was replaced by $\mathrm{KCl}$.

The preparation was stimulated electrically at the rate of $0.2 \mathrm{cps}$ throughout the experiment, except when K-contracture was induced and recorded. The stimulation was made by a square wave pulse, $5 \mathrm{msec}$ duration, of an electronic stimulator (Nihon Kohden, MSE-3R) via a hook holding the lower end of the preparation. The contractile tension was recorded isometrically on a linear recorder (Watanabe Electronic Instruments, WTR281) with the aid of a straingauge transducer and a carrier amplifier. To the transducer, the upper end of the preparation was connected by string.

2) Isolated heart preparation (Straub's preparation): Experiments were performed at a room temperature (20-25\%). Straub's cannula contained $2 \mathrm{ml}$ of Ringer's solution aerated with air. The contraction of the heart was recorded by an isotonic lever. The heart was made hypodynamic by reducing the concentration of calcium to $0.6 \mathrm{mM}$, one third the normal, and then the effect of a cardiotonic steroid was tested in the following way.

The stock solution of a test compound was diluted with distilled water. Starting from a subthreshold dose, a small amount $(0.02-0.14 \mathrm{ml})$ of a diluted solution was added to the cannula every fifteen minutes, so that a stepwise increase in the cummulative concentration of the compound was achieved. The way of increase in the cummulative concentration was: $10^{-\mathrm{n}}, 3 \times 10^{-\mathrm{n}}, 10^{-(\mathrm{n}-\mathrm{)})}, 3 \times 10^{-(\mathrm{n}-1)}, 10^{-(\mathrm{n}-2)}, \ldots$ Usually, three or four steps were sufficient to cover from the minimum effective concentration to that causing systolic arrest of the heart. At least three experiments were carricd out with each compound.

Compounds used: Three aglycones and four derivatives of digitoxigenin were used

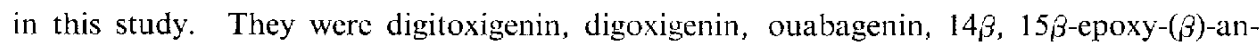

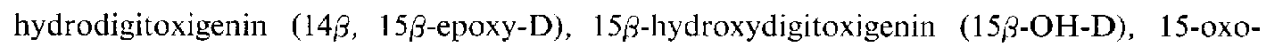
digitoxigenin (15-oxo-D) and dihydrodigitoxigenin (2H-D).

The dirivatives of digitoxigenin were synthesized by Dr. M. Okada of the Tokyo Biochemical Research Institute, Tokyo. All the compounds used were kindly supplied by him.

Stock solutions of the agents were prepared, by dissolving each compound in $70 \%$ ethanol in concentration of $1 \mathrm{mg} / \mathrm{ml}$. In the experiment with the ventricular strip prcparation, the stock solution was diluted with $0.9 \mathrm{mM}$ Ca Ringer to a desired concentration, and this replaced the bathing fluid. In Straub's preparation, the stock solution was diluted with distilled water as stated above.

\section{RESULTS}

I) Assay of aglycones by the isolated ventricular strip preparation

1) Study on experimental conditions: The relationship between the contracture tension and concentrations of polassium and calcium was first examined. The results are illustrated in Fig. 1. From this figure, it was decided to use $110 \mathrm{mM} \mathrm{K}, 5 \mathrm{mM} \mathrm{Ca}$-Ringer for the determination of the maximal contracture tension. 


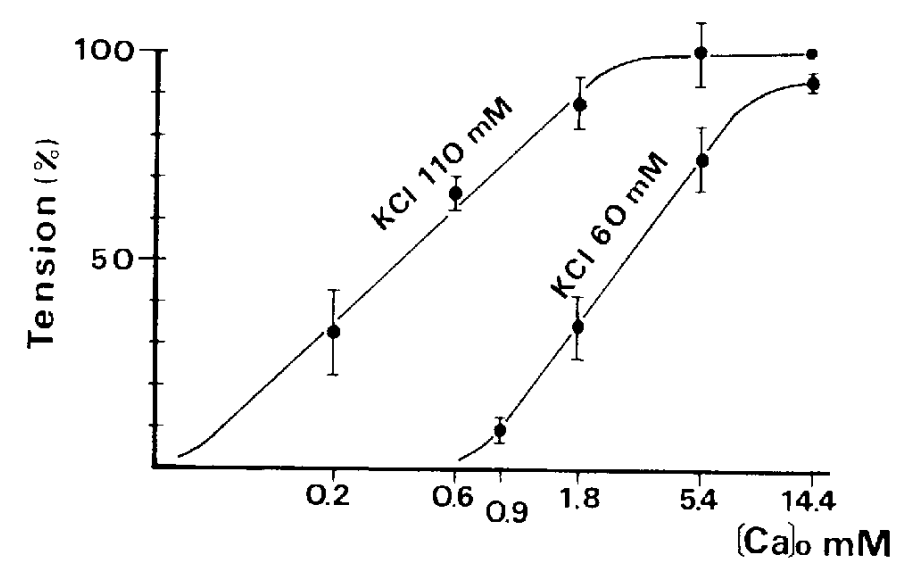

F1G. 1. Effects of potassium and calcium on the development of the contracture tension of the isolated frog ventricular muscle.

The maximal tension could also be induced by $60 \mathrm{mM} \mathrm{K}$-Ringer, if the concentration of calcium was $14.4 \mathrm{mM}$ or more. In this case, however, the tension development was much suppressed in the presence of a higher dose of a cardiotonic steroid, the toxic effect of the latter being greatly potentiated, and the measurement of the maximal tension was often impossible. Furthermore, when the induction of contracture of the muscle by 60 $\mathrm{mM} \mathrm{K}, 14.4 \mathrm{mM}$ Ca-Ringer was repeated many times, the developed tension increased steadily over a period of 4 hours or even more, and no stable state could be obtained. In contrast, when $110 \mathrm{mM} \mathrm{K}, 5 \mathrm{mM}$ Ca-Ringer was used, a stable state was attained within 2 hours as described below.

For measurement of potentiating effect of K-contracture by cardiotonic steroids, 60 $\mathrm{mM} \mathrm{K}, 0.9 \mathrm{mM} \mathrm{Ca}-\mathrm{Ringer}$ was chosen. In this medium the tension of the muscle was usually around $10 \%$ of the maximum (Fig. 1). So there is plenty of room left for a cardiotonic steroid to improve the tension development.

2) Measurement of the maximal tension and its time course: After dissection, the preparation was first equilibrated for 30 minutes in $0.9 \mathrm{mM}$ Ca-Ringer of which composition was the same as the normal except for $\mathrm{CaCl}_{2}$. Then the bathing solution was replaced with $5 \mathrm{mM}$ Ca-Ringer. After a lapse of 20 minutes, during which time the twitch tension became progressively greater till it reached a steady higher level, contracture was induced by replacing the bathing medium with $110 \mathrm{mM} \mathrm{K}, 5 \mathrm{mM}$ Ca-Ringer and the maximal tension was recorded. Immediately, then, the preparation was washed with $0.9 \mathrm{mM} \mathrm{Ca}$ Ringer, and was again bathed in $5 \mathrm{mM}$ Ca-Ringer for another 20 minutes, and the maximal contracture was induced and recorded. The same procedure was

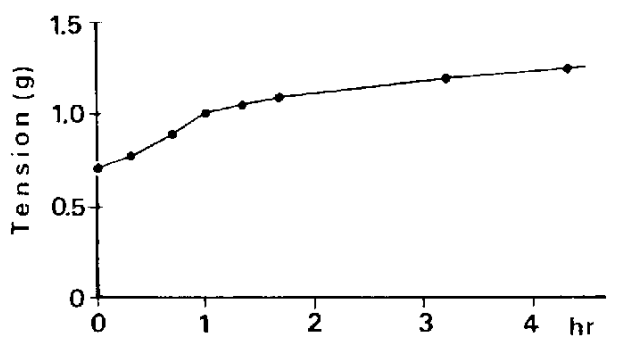

Frg. 2. Time course of the maximal tension development induced by $110 \mathrm{~mm} \mathrm{~K}, 5 \mathrm{~mm}$ Ca-Ringer in a ventricular muscle preparation. 
repeatcd several times in succession until the developed tension reached a steady level. As shown in Fig, 2, this was usually attained within two hours.

3) Assay procedure: As soon as the maximal contracture tension became steady (Fig. 3, A, $\mathrm{T}_{\mathrm{max}}$ ), the assay of the test compound was started. In Fig. 3, a typical example of the procedure is shown. After the preparation was washed with $0.9 \mathrm{mM}$ Ca-Ringer, it was bathed in $0.9 \mathrm{mM} \mathrm{Ca}$-Ringer containing a low dose of the test compound. Forty five minutes was allowed to elapse during which time the twitch tension increased gradually till it reached a steady higher level. The bathing fluid was renewed once in the middle of this period. Then K-contracture was induced by replacing the bathing fluid with 60 mM K, $0.9 \mathrm{mM}$ Ca-Ringer and recorded (Fig. 3, B, Tluw).

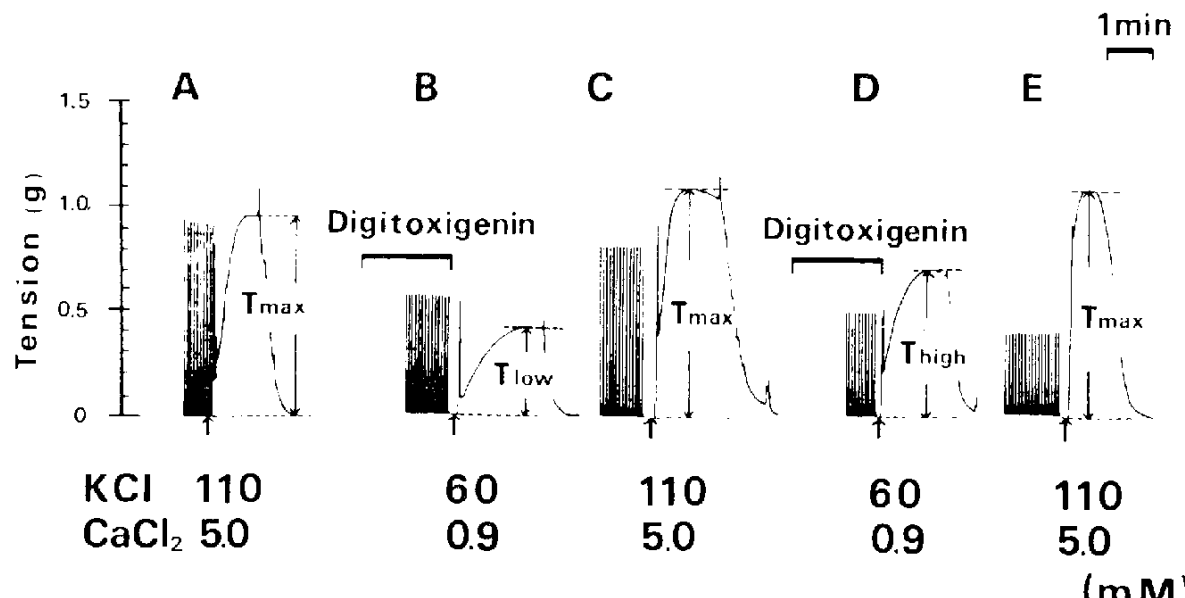

FiG. 3. A typical example of the assay procedure. $\mathrm{T}_{\max }$ : maximal contracture tension. $\mathrm{T}_{\text {low }}$ and $\mathrm{T}_{\mathrm{b} \mathrm{I}_{\mathrm{gh}}}$ : Contracture tension developed in the presence of low dose and high dose of digitoxigenin, respectively. At the arrows, the bathing fluid was replaced by a modified Ringer's solution which contained $\mathrm{KCl}$ and $\mathrm{CaCl}_{3}$ in concentrations as indicatcd by the figures at the bottom.

After washings with $0.9 \mathrm{mM} \mathrm{Ca}$-Ringer, the preparation was immersed in $5 \mathrm{mM} \mathrm{Ca}$ Ringer for 20 minutes and the maximum contracture tension was again recorded (Fig. 3, C, $\mathrm{T}_{\text {max }}$ ). The preparation was washed with $0.9 \mathrm{mM} \mathrm{Ca-Ringer,} \mathrm{and} \mathrm{was} \mathrm{bathed} \mathrm{in}$ $0.9 \mathrm{mM}$ Ca-Ringer which contained a high dose of the test compound. After another 45 minutes, with a renewal of the solution in about the middle of the period, K-contracture was induced and recorded as in the case of the low dose of the compound (Fig. 3, D, $T_{\text {higl }}$ ).

Upon completion of the above procedure, the preparation was washed and bathed in $5 \mathrm{mM}$ Ca-Ringer for 20 minutes, and the final determination of the maximal tension was made (Fig. 3, E, $T_{\text {max }}$ ).

The three maximal tension values obtained at the beginning, in the middle and at the end of the assay were plotted against time, and the maximal tensions to be obtained at the time of measurements of $T_{\text {low }}$ and $T_{h i g h}$ were estimated from this graph by interpolation. $\mathbf{T}_{\mathrm{ln} w}$ and $\mathbf{T}_{\mathrm{high}}$ were expressed as percentage of the maximal tensions estimated in this way. 
The low and high doses of each compound were determined by pilot experiments.

A rough estimation of the potency of an aglycone was first made by measn of Straub's preparation. Then a preliminary assay was performed with the compound of several graded doses, and a dose-response curve was made. From this, the dose of the compound which would produce a contracture tension of about $40 \%$ of the maximum was taken as the low dose. The high dose was three times as much as the low dose. The high dose of a compound usually produced about $70 \%$ of the maximal tension.

Digitoxigenin and one or two other compounds made one group of the assay. In order to minimize the variation in response, each group of compounds were tested on the same batch of frogs. Four or six experiments were carried out for each of the compounds tested.

TABLE 1. Results of assay of seven aglycones by the new method.

\begin{tabular}{|c|c|c|c|c|c|c|}
\hline & \multicolumn{2}{|c|}{$\begin{array}{c}\text { Concentration } \\
(\mu / \mathrm{ml})\end{array}$} & \multicolumn{2}{|c|}{$\begin{array}{c}\text { K-contracture tension* } \\
(\% \text { of maximum })\end{array}$} & \multirow[t]{2}{*}{$\begin{array}{l}\mathrm{ED}_{50} * * \\
(\mu \mathrm{g} / \mathrm{ml})\end{array}$} & \multirow[t]{2}{*}{ Relative potency**** } \\
\hline & Low & High & Low & High & & \\
\hline \multicolumn{7}{|l|}{ Group A } \\
\hline Digitoxigenin & 0.12 & 0.36 & $41.6 \perp 8.1$ & 69.0 上 2.1 & 0.16 & 1.00 \\
\hline Digoxigenin & 0.30 & 0.90 & $50.2+3.1$ & $74.9 \pm 4.4$ & 0.30 & $0.54(0.40-0.73)$ \\
\hline \multicolumn{7}{|l|}{ Group B } \\
\hline Digitoxigenin & 0.12 & 0.36 & $36.8 \pm 6.8$ & $63.5 \pm 6.6$ & 0.21 & 1.00 \\
\hline Ouabagenine & 0.30 & 0.90 & $40.7+8.3$ & 75.2 .11 .8 & 0.39 & $0.53(0.37-0.77)$ \\
\hline \multicolumn{7}{|l|}{ Group C } \\
\hline Digitoxigenin & 0.12 & 0.36 & $46.9 \pm 7.3$ & $78.9 \pm 2.0$ & 0.14 & 1.00 \\
\hline $14 \bar{\beta}, 15 \beta$-ерохy-D & 0.30 & 0.90 & $42.1: 7.7$ & 83.9 上 2.6 & 0.36 & $0.40(0.33-0.49)$ \\
\hline $15 \beta-\mathrm{OH}-\mathrm{D}$ & 1.80 & 5.40 & $43.6 \pm 2.9$ & $82.7 \pm 6.3$ & 2.1 & $0.067(0.055-0.082)$ \\
\hline \multicolumn{7}{|l|}{ Group D } \\
\hline Digitoxigenin & 0.12 & 0.36 & $24.2: 2.4$ & $56.4+6.1$ & 0.27 & 1.00 \\
\hline $2 \mathrm{H}-\mathrm{D}$ & 4.50 & 13.50 & $26.4=8.1$ & $76.6 \pm 11.0$ & 7.5 & $0.036(0.028-0.046)$ \\
\hline 15-0xo-D & 10.00 & 30.00 & $27.1 \pm 6.7$ & $70.1 \pm 7.1$ & 18.0 & $0.015(0.012-0.019)$ \\
\hline
\end{tabular}

* mcan $上$ S.D., $n=4$ in Group A, C, D; $n=6$ in Group B.

** $\mathrm{ED}_{50}$ : Concentration of a compound necessary to produce $50 \%$ of the maximal tension of the muscle.

*** Digitoxigenin served as the reference standard in each group. Figures in parentheses are $95 \%$ confidence limits.

$14 \beta, 15 \beta$-epoxy-D : 14 $\beta, 15 \beta$-epoxy- $\beta$-anhydrodigitoxigenin, $15 ;-0 \mathrm{H}-\mathrm{D}: 15 \beta$-hydroxydigitoxigenin, 2H-D : dihydrodigitoxigenin, 15-oxo-D : 15-oxadigitoxigenin.

4) Relative potencies of seven aglycones: In Table 1, the results of assay of scven aglycones are summarized.

The values of $E D_{50}$ (the concentration of a compound necessary to produce $50 \%$ of the maximal contracture tension) and the relative potency were obtained according to the parallel line assay technique. The confidence limits for relative potency were calculated on the basis of Filler's theorem. Since, the present method does not allow the standard and the test compounds to be tested on one and the same preparation, there occur two independent variances. Thus, theoretically, the Bchrens distribution should be used for calculation of the confidence limits (5). However, t-distribution has been utilized as 


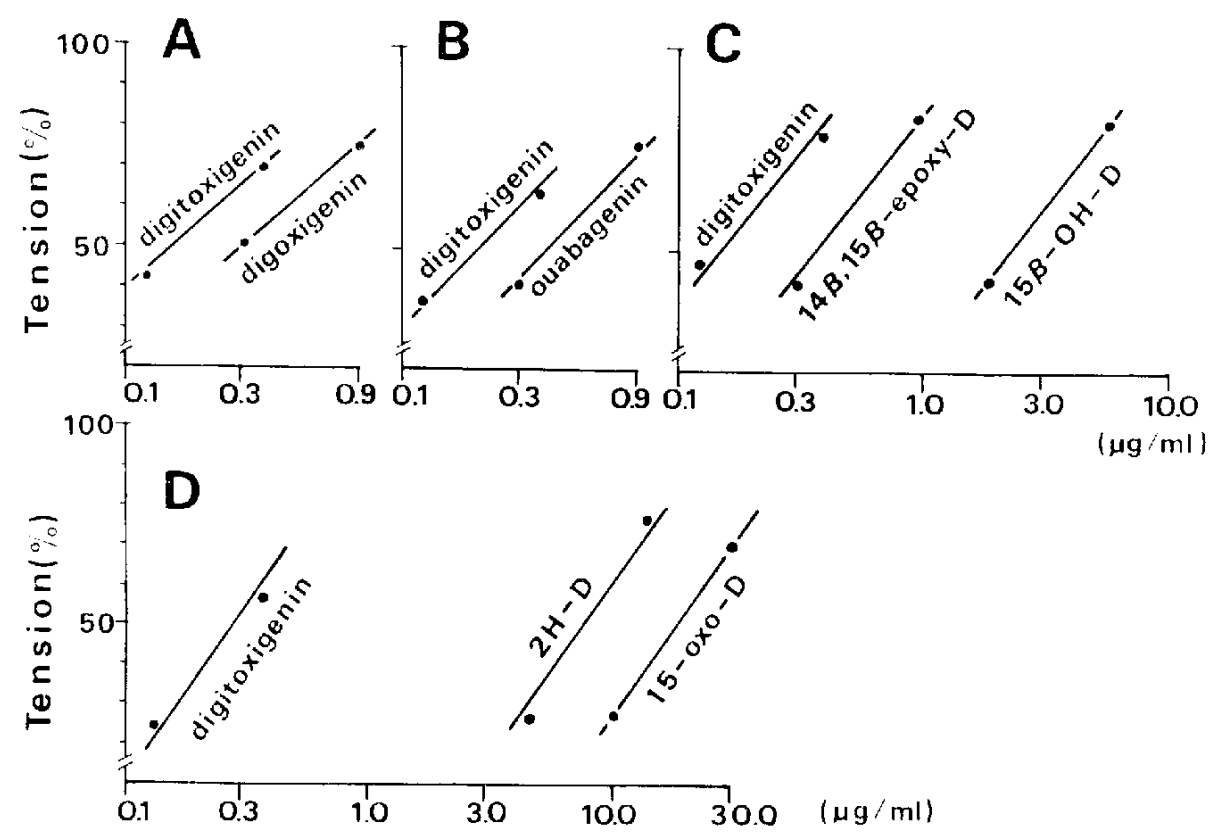

FIG. 4. Results of the assay of seven aglycones by the new method. In each group, digitoxigenin served as the reference standard. Abbreviations are the same as in Table 1.

an approximation, since the degrees of freedom of the two variances are equal. As digitoxigenin served as the standard compound in each group of assay, the multiple t-distribution of Dunnett $(6,7)$ rather than $t$-distribution has been utilized, in groups $C$ and $D$.

The mean values of $\mathrm{K}$-contracture tensions as percentage of the maximal tension are plotted in Fig. 4. The parallel lines are drawn, the common slope of which being calculated in each group of assay. The slope values in groups A-D were 54.5, 64.1, 78.8 and 87.7 , respectively.

II) Assay of aglycones with the isolated frog's heart (Stratb's preparation)

The positive inotropic effects of the seven aglycones were also tested on Straub's prepa-

TABLE 2. Comparison of the relative potencies (R.P.) of seven aglycones obtaincd by "K-contracture method" and those obtained by means of Straub's preparation. Note a close agreement between R.P. regarding potentiated K-contracture and R.P. regarding systolic arrest. Other abbreviations are the same as in Table 1.

\begin{tabular}{|c|c|c|c|c|c|}
\hline \multirow[b]{3}{*}{ Digitoxigenin } & \multirow{3}{*}{$\begin{array}{c}\text { Ventricular strip preparation } \\
\text { (K-contracture) } \\
\text { R.P. } \\
1.00\end{array}$} & \multicolumn{4}{|c|}{ Straub's preparation } \\
\hline & & \multicolumn{2}{|c|}{$\begin{array}{c}\text { Minimal effective conc. } \\
(\mu \mathrm{g} / \mathrm{m} \mathrm{l})\end{array}$} & \multicolumn{2}{|c|}{$\begin{array}{l}\text { Systolic arrest } \\
(t \mathrm{~g} / \mathrm{ml})\end{array}$} \\
\hline & & 0.03 & 1.0 & 0.3 & 1.0 \\
\hline Digoxigenin & $0.54(0.40-0.73)$ & 0.1 & 0.3 & $0.3-1.0$ & $0.3-1.0$ \\
\hline Ouabagenin & $0.53(0.37-0.77)$ & 0.1 & 0.3 & $0.3-1.0$ & $0.3-1.0$ \\
\hline $14 \beta, 15 \beta$-epoxy-D & $0.40(0.33-0.49)$ & $0.03-0.1$ & $0.3-1.0$ & $0.3-1.0$ & $0.3-1.0$ \\
\hline $15 \beta-\mathrm{OH}-\mathrm{D}$ & $0.067(0.055-0.082)$ & 0.3 & 0.1 & $3-10$ & $0.03 \cdot 0.1$ \\
\hline $2 \mathrm{H}-\mathrm{D}$ & $0.036(0.028 \cdot 0.046)$ & 0.3 & 0.1 & 10 & 0.03 \\
\hline 15-oxo-D & $0.015(0.012-0.019)$ & 3.0 & 0.01 & 30 & 0.01 \\
\hline
\end{tabular}


ration. The minimal effective concentration and the concentration in which systolic arrest of the heart was induced were obtained for each of the compounds. The relative potency was calculated on the basis of these data, and compared with the valucs obtained by the "K-contracture method". As shown in Table 2, there is a close agreement between the two sets of values of relative potency, namely, those regarding potentiation of K-contracture and those regarding induction of systolic arrest.

\section{DISCUSSION}

Little success has so far been achieved in measuring the positive inotropic activity of the cardiotonic sleroids preciscly, by the isolated heart or the cardiac muscle preparations. The importance of a method of this sort in the study of the structure-activity relationship of the compounds was discussed previously (2). A major problem seems to be the difficulty in obtaining suitable dose-response relationship, due to the slowness of these compounds in reaching a full effect, little washability, and the involvement of suppressive effects on excitation of the muscle cell membrane especially in higher doses.

A trial was made by White and Salter (8). They oblained dose-response curves of some glycosides on the basis of their positive inotropic effects on the isolated papillary muscle of the cat. The relative potencics were calculated by an appropriate statistical analysis. This method, however, doesn't seem to be practical, because the assay procedure is not very simple, and because the size of the maximal response is not certain.

In the present study, the usage of potentiation of $\mathrm{K}$-contracture and the selection of adequate ionic conditions made it possible to obtain satisfactory results, which could be treated according to the parallel line assay technique. Seven agleyones were assayed by the new method. The index of precision $(\lambda)$ of the method was 0.10 on the average. This value is about the same as that of the insulin assay by means of measuring the rabbit blood sugar level (7).

The advantage of taking the K-contracture tension as the measure of the positive inotropic effect of the steroids, instead of taking the twitch tension, is shown in the study of Otsuka and Nonomura (9) on the action of ouabain on the isolated frog ventricular muscle. They showed that the augmentation of $\mathrm{K}$-contracture persisted even after the onset of the toxic stage of the onabain action, while the twitch tension became markedly depressed. Therefore, a wider dosage range of a compound is available for the sasay when the potentiation of $\mathrm{K}$-contracture is utilized as the measure.

As stated above, a close agreement was noticed between the relative potencies calculated on the basis of the increased K-contracture of the ventricular muscle and those which were calculated on the basis of systolic arrest in Straub's preparations. This may be reasonable, because both phenomena are the results of the same action of the compounds; namely the action causing a shift of the depolarization-tension relationship of ventricular muscle (9). The finding assures that Straub's preparation is useful enough for a rough comparison of the activity of the cardiotonic steroids.

In this context, it was also found that there exists a good correlation between the ac- 
tivity in potentiating the K-contracture and that in inhibiting the Na, K-activated ATP-ase of pig brain, among some of the compounds tested (10).

So far, the present method has been applicable only to aglycones, and not to glycosides which are much slower in action. A trial was made to measure the effect of ouabain by the same assay procedure. Potentiation of K-contracture, however, continued to progress for many hours, and no steady state could be attained. It held true, even when the ratc of electrical stimulation of the muscle was increased $101 \mathrm{cps}$, although the development of the glycoside action was much faster (unpublished observation). The fact that the rate of progress of the positive inotropic effect of cardiotonic steroids depends on the stimulation frequency was reported by some authors $(11,12)$. At present, extension of the principle of the present method to glycosides needs further study.

It may be stated, however, that the present method is quite useful, providing precise values of the relative potency of aglycones, since aglycones and their derivatives are very important for the study of the structure-activity relationship.

\section{SUMMARY}

A new method for the biological assay of the cardiotonic steroids was devcloped. Potentiation of K-contracture of the isolated frog ventricular muscle was utilized as the measure of the positive inotropic activity. Experiments are designed on the parallel line assay scheme. The method is so far successfully applied to the assay of aglycones.

Seven aglycones were assayed. The relative potencies (with $95 \%$ confidence limits) obtained were: digitoxigenin 1.00; digoxigenin $0.54(0.40-0.73)$; ouabagenin $0.53(0.37-$ $0.77) ; 14 \beta, 15 \beta$-cpoxy-( $\beta)$-anhydrodigitoxigenin $0.40(0.33-0.49) ; 15 \beta$-hydroxydigitoxigenin $0.067(0.055-0.082)$; dihydrodigitoxidgenin $0.036(0.028-0.046) ; 15$-oxodigitoxigenin 0.015 (0.012-0.019).

A close agreement was seen between these values and the rclative potencies which were calculated on the basis of systolic arrest of Straub's frog heart preparation.

Acknowledgements: The authors wish to express their gratitude to Dr. M. Okada (Tokyo Biochemical Research Institute) for his kind supply of the compounds used in this study, and to Dr. S. Imai (Department of Pharmacology, Niigata University, School of Medicine) for his valuable help and advice. Thanks are also due to Mrs. Y. Orihashi and Mr. M. Sekiguchi for their assistance.

\section{REFERENCES}

1) Shighi, T., Katori, M., Murase, H. and Imai, S.: Experientia 20, 572 (1964)

2) Imai, S., Murase, H., Katori, M., Okada, M. and Shigei, T.: Jap. J. Pharmac. 15, 62 (1965)

3) Shigei, T. And Mineshita, S.: Experientia 24, 466 (1968)

4) Taklda, K., Shiciei, T. and Imai, S.: Experientia 26, 867 (1970)

5) Finnfy, D.J.: Statistical Method in Biological Assay, 2nd Ed., p, 29, Charles Griffìn \& Co., London (1964)

6) DunnetT, C.W.: Biometrics 20, 482 (1964) 
7) Sakuma, A.: Bioassay-Design and Analysis, p. 188 and 227, Univ. of Tokyo Press, Tokyo (1964) (in Japanese)

8) White, W.F. and Salter, W.T.: J. Pharmac. exp. Ther. 88, 1 (1946)

9) Otsuka, M. and Nonomura, Y.: J. Pharmac. exp. Ther. 141, 1 (1963)

10) Shigfi, T., TAkeda, K., TAShima, Y. ANd NAKAo, M.: Experientia 27, 415 (1971)

11) Wilbrandt, W., Brawand, K. and Wilt, P.N.: Arch. exp. Path. Pharmak. 219, 397 (1953)

12) Moran, N.C.: Proc. of the First Internat. Pharmac. Meeting, 3, p. 251, Pergamon Press, Oxford (1963) 